\title{
THE
}

\section{Financial Capability of Student Loan Holders Who are College Students, Graduates, or Dropouts}

Jing Jian Xiao

University of Rhode Island, xiao@uri.edu

Nilton Porto

University of Rhode Island, nilton_porto@uri.edu

Irene Mclvor Mason

University of Rhode Island

Follow this and additional works at: https://digitalcommons.uri.edu/hdf_facpubs

The University of Rhode Island Faculty have made this article openly available.

Please let us know how Open Access to this research benefits you.

This is a pre-publication author manuscript of the final, published article.

Terms of Use

This article is made available under the terms and conditions applicable towards Open Access

Policy Articles, as set forth in our Terms of Use.

\section{Citation/Publisher Attribution}

Xiao, J. J., Porto, N., \& Mason, I. M. (2020). Financial capability of student loan holders who are college graduates, dropouts, and enrollees. Journal of Consumer Affairs, 54(4), 1383-1401. https://doi.org/ 10.1111/joca. 12336

Available at: https://doi.org/10.1111/joca.12336

This Article is brought to you for free and open access by the Human Development and Family Science at DigitalCommons@URI. It has been accepted for inclusion in Human Development and Family Science Faculty Publications by an authorized administrator of DigitalCommons@URI. For more information, please contact digitalcommons-group@uri.edu. 
Xiao, J. J., Porto, N., \& Mason, I. M. (2020). Financial capability of student loan holders who are college graduates, dropouts, and enrollees. Journal of Consumer Affairs, 54(4), 1383-1401.

https://doi.org/10.1111/joca.12336

\title{
Financial Capability of Student Loan Holders Who are College Students, Graduates, or Dropouts
}

\begin{abstract}
Effective consumer financial education provides relevant information to meet special needs of targeted audiences. The purpose of this study is to examine differences in financial capability among student loan holders who are college students, graduates, and dropouts. Using data from the 2015 U.S. National Financial Capability Study, the results show that student loan holders who have completed their education program have higher scores in all financial capability indicators than college students and dropouts. Further analyses show differences in specific financial knowledge items among college students, graduates, and dropouts. In addition, college graduates are more likely to perform several specific desirable financial behaviors than college students and dropouts. The findings suggest that financial educators should emphasize action taking when they provide financial education for student loan holders who are college students and dropouts.
\end{abstract}




\section{Financial Capability of Student Loan Holders}

\section{Introduction}

Student loan holding is a current important policy issue in the U.S.. Research shows that between 2000 and 2014, student loan debt nearly quadrupled to surpass $\$ 1.1$ trillion, the number of student loan borrowers more than doubled to reach 42 million, and default rates among recent student loan borrowers rose to the highest levels in 20 years (Looney and Yannelis 2015). According to the 2015 National Financial Capability Study (Lin et al. 2016), 26\% of the U.S. population hold student loans. Many student loan holders lack knowledge about their loans. Only $35 \%$ of the loan holders knew if their loan repayment plan is income-based and $19 \%$ did not know; $53 \%$ did not estimate the monthly repayment cost of their student loans when they were offered loans. Among those who borrowed student loans to attend colleges/universities, $28 \%$ did not complete the degree/program (Lin et al. 2016). As suggested by previous research, effective financial education programs should focus on specific needs of students (Alsemgeest 2015; Bartholomae and Fox 2016). To encourage repayment of student loans after graduating or dropping out of colleges/universities, consumer educators should better inform these student loan holders through effective targeted financial education programs including online exit counseling at the time of graduation. To achieve this goal, knowledge creators and knowledge distributors should work together creatively (Hill 2019). As the first step, we have researched differences in financial capability among student loan holders with various education attainments.

The purpose of this study is to examine differences of financial capability among three types of student loan holders: college students, graduates, and dropouts. The research question is: What are differences in financial capability factors in the three groups of student loan holders? Financial capability can be broadly considered "a multi-dimensional concept that encompasses a combination of knowledge, resources, access, and habits" (Lin et al. 2016, 2). In 


\section{Financial Capability of Student Loan Holders}

this study, a narrower definition is used in which financial capability is defined as the ability to apply financial knowledge and engage in desirable financial behavior for achieving financial wellbeing (Xiao and O’Neill 2016; Xiao and Porto 2017).

Following previous research (Xiao and Porto 2017), four indicators and one index are used to measure financial capability: objective financial knowledge, subjective financial knowledge, desirable financial behavior, and perceived financial capability. The index of financial capability is a sum of Z-values of the four indicators of financial capability. The findings of this study have direct implications for consumer educators and policy makers for developing effective educational programs tailored to meet diverse needs of these student loan holders. Specifically, any differences found among the three types of student loan holders will be informative for policy makers when they make relevant policies for promoting consumer financial capability and wellbeing. Detailed analyses of group differences in terms of specific knowledge items and behaviors will inform consumer educators to tailor their education materials and approaches to address the diverse needs of three types of student loan holders with various education completion statuses.

\section{Literature Review}

Research on student loan issues has been conducted from a variety of perspectives, such as cost and benefits of student loan borrowing (Avery and Turner 2012), predictions of loan default (Flint 1997), legal debates of student loan options (Miller 2004), and disparities of student loan burdens (Houle 2014). Researchers have also studied topics such as college financing (Cigno and Luporini 2009), education policy (Lochner and Monge-Naranjo 2015), and general trends of student loans (Burr 2016; Chapman 2006; Looney and Yannelis 2015). 


\section{Financial Capability of Student Loan Holders}

One line of research studying consumer behavior of student loan holding shows that student loan holding is an important factor contributing to the stress of college students. Among college students, student loan debt is positively associated with financial anxiety (Archuleta, Dale, and Spann 2013). College students are more likely to experience financial stress when they have student loan debt as compared to those without student loan debt (Britt et al. 2015). College students with higher student loan debts are more likely to seek help from financial professionals (Lim et al. 2014).

College students' knowledge level regarding student loans is low and providing relevant information for them may affect their financial and academic behaviors. Research shows that students rely heavily on advice from parents, guidance counselors, and friends; and they know very little about the loans they will be responsible for repaying (Johnson et al. 2016). Firstgeneration students are more likely to use student loans than continuing-generation students (Lee and Mueller 2014). Student loan information provision may impact college students' borrowing decisions, especially some key subgroups such as those with low GPAs (Darolia 2016). Provision of student loan information through a simple "Know Your Debt" letter may also affect students' academic choices (Schmeiser, Stoddard, and Urban 2016).

Many researchers have also identified other factors associated with student loan debts and debt behavior. Research shows that family income and college experiences are strongly associated with the probability of zero debt burden as well as the level of debt burden; graduates from private institutions have a higher level of debt burden than graduates from public institutions; and state funding of merit-based aid programs plays a role in reducing students' debt burden (Chen and Wiederspan 2014). Another study indicates that among student loan holders, individuals who received financial education in an academic or professional setting are less 


\section{Financial Capability of Student Loan Holders}

likely to be late on student loan payments or worry about their student loan debt (Fan and Chatterjee 2019). Financial independence is positively associated with both credit card borrowing and student loan debt of college students (Kim, Chatterjee, and Kim 2012).

Individuals who have borrowed from both federal and private sources or private lenders only are less likely to indicate that they would make the same borrowing decisions (Robb et al. 2019).

Student loan borrowing has significant consequences on borrowers' personal lives. A literature review concludes that student loan debt may negatively affect young adults' health and transition to adulthood outcomes (Cho, $\mathrm{Xu}$, and Kiss 2015). For example, holding student loans is associated with poorer psychological functioning among young adults aged 25-31

(Walsemann, Gee, and Genti 2015). Increases of \$1,000 in student loan and credit card debt result in $6 \%$ and $4 \%$ higher odds of distress, respectively among young adults aged 18-28 (Zhang and Kim 2019). Earlier student loan debts are negatively associated with health status among Hispanic students (Kim and Chatterjee 2019). Researchers have called for higher education institutions to better understand the needs of college students and effectively plan and implement financial wellness initiatives on campus (Montalto et al. 2019).

\section{Conceptual Framework and Hypotheses}

Based on the seminal work of Erikson (1982), the psychosocial theory of human development offers an organizational framework for considering individual development within the larger perspective of psychosocial evolution. One of the key concepts of psychosocial theory are the "stages of development" that include specific developmental milestones by age ranges (Newman and Newman 1999). Each developmental stage faces unique psychosocial tasks, crises, solving processes, radiating networks, and coping skills (Newman and Newman 1999). Relevant 


\section{Financial Capability of Student Loan Holders}

to this study are the developmental age ranges of adolescence (18 to 24), early adulthood (24 to 34), middle adulthood (34 to 60), later adulthood (60 to 75$)$ and very old age (75 until death).

Later adolescence is also called emerging adulthood in the human development literature (Arnett 2000). For the purpose of the conceptual discussion, we considered two age groups, people aged 18-24 as emerging adults and people 25 and over as older adults.

In the context of financial capability and in terms of financial independence, two major age groups exist, emerging adults who are attending college and investing human capital to gain earning potential and older adults who are financially independent and fulfilling obligations (including repayment of student loans). These two age groups have demonstrated different levels of financial knowledge, financial behavior, and financial capability (Agnew and CameronAgnew 2015; Braun Santos et al. 2016; Letkiewicz and Fox 2014; Montford and Goldsmith 2016; Murendo and Mutsonziwa 2017; Riitsalu and Põder 2016; Xiao et al. 2011; Xiao, Chen, and Sun 2015). In this study, older adults have two subgroups, one group includes college graduates and the other includes college dropouts. Previous research shows that even among young adults, levels of financial capability are different among college enrollees, graduates, and dropouts (Xiao, Chatterjee, and Kim 2014). We expect these differences to persist as people grow older.

In this context, we assume that financial capability can be determined by two factors: cognitive ability and life experience. Based on the relevant theories and empirical research, we have created Figure 1 that summarizes the conceptual discussion on financial capability among student loan holders who have various education attainment statuses through borrowing student loans. Based on this conceptual framework, we discuss and propose three hypotheses below. 


\section{Financial Capability of Student Loan Holders}

As mentioned in the introduction, financial capability is defined as an integration of financial knowledge and financial behavior. Levels of financial knowledge and performances of financial behaviors are dependent on both cognitive ability and life experience. For simplicity, we assume that financial knowledge is mainly related to cognitive ability and financial behavior is mainly related to life experience. If these assumptions hold, we expect that both college graduates and enrollees have more financial knowledge because they have higher cognitive abilities than college dropouts (there are of course exceptions, such as famous college dropouts like Bill Gates and Mark Zuckerberg). Researchers find significant differences in the likelihood of entrepreneurship among dropouts and graduates. Except at the upper end of the income distribution, entrepreneurship does not allow college dropouts to compensate for their disadvantages in the labor market (Buenstorf, Nielsen, and Timmermans 2017). Lack of academic ability may be the major reason for dropping out of college (Hendricks, Lutz, and Oksana Leukhina, 2017). Research on community college students shows that math and science credits earned in the first and second year are most predictive of completion among the matched group of students who have earned a high number of credits but dropped out in the middle of an academic program (Park 2019). We acknowledge that this is only an assumption since some people may be dropping out of college for other reasons such as getting married (a famous example is the former first lady, Barbara Bush). Previous research shows that education levels are positively associated with financial knowledge levels (Lusardi and Mitchell 2014; Xiao and Porto 2017). Thus, the following hypothesis is proposed:

H1: Among student loan holders, college graduates and enrollees have higher levels of financial knowledge than college dropouts. 


\section{Financial Capability of Student Loan Holders}

Financial behaviors refer to any behaviors relevant to money management. As people age, their finances become more complicated and they engage in more financial behaviors than younger individuals (Xiao, Chen, and Sun 2015). Compared to young adults aged 18-24, older adults are more likely to perform desirable financial behaviors (Henager and Cude 2016). Based on the assumption that financial behaviors are most related to life experience and given the fact that, on average, college graduates and dropouts are older than college enrollees, we predict that both college graduates and college dropouts should perform more desirable financial behaviors.

H2: Among student loan holders, college graduates and dropouts perform more desirable financial behaviors than college enrollees.

Financial capability can be defined in various ways (Lin et al. 2016). It can be defined as financial knowledge (Lusardi and Mitchell 2014) and its application of financial knowledge (Huston 2010). In this study, we define it as the ability to apply financial knowledge and engage in desirable financial behavior (Xiao and Porto 2017). We further predict that college graduates will have a higher level of financial capability than the other two groups because they possess more cognitive ability than college dropouts and more life experience than college enrollees. Differences in financial capability between college dropouts and enrollees are ambiguous depending on several factors such as weights of financial knowledge and financial behavior effects on the overall financial capability. Thus, the following hypothesis is proposed:

H3: Among student loan holders, college graduates have a higher level of financial capability than college enrollees and dropouts.

\section{Methods}

\section{Data}




\section{Financial Capability of Student Loan Holders}

Data used in this study was from the 2015 U.S. National Financial Capability Study (NFCS), commissioned by the FINRA Investor Education Foundation and conducted by Applied Research and Consulting LLC. Background information about this data set can be found in Lin et al. (2016). Started in 2009, the NFCS is composed of triennial surveys that have been widely used and validated as a representative sample of the American population by researchers in economics, business, consumer finance, and other social science fields. The 2015 survey included several new questions about student loans. In this study, only respondents who had student loans for their own education programs were selected. To accurately identify education attainments of these student loan holders, we used multiple variables. For college graduates, we used G34=1 (completed the education program from which borrowed money) and A5=6 or 7 (bachelor's degree or postgraduate degree) to capture college graduates and a limited number of postgraduates). For college dropouts, we used G34=2 (did not complete the education program from which borrowed money) and A5=4 (some college, no degree). For current college students, we used a combination of G34=3 (still enrolled in the education program from which borrowed money) and A22=1 (attending 4-year college or university), which resulted in a sample size of 3,312, among which 2,065 completed, 762 dropped out, and 485 were enrolled in a higher education program. These subgroups of student loan holders were examined in this study because they may have differences in financial knowledge, behavior, and capability so that their needs for financial education may be different.

\section{Variables}

Table 1 presents specifications of variables used in this study including the original wordings of several variables. Following previous research (Xiao et al. 2015), financial capability variables include four indicators and one index. The four indicators are objective 


\section{Financial Capability of Student Loan Holders}

financial knowledge, subjective financial knowledge, desirable financial behavior, and perceived financial capability. Financial knowledge was measured by the objective and subjective financial knowledge variables. Previous research suggested that these two types of knowledge have different effects on consumer behavior (Xiao et al. 2011). Objective financial knowledge was the quiz score of six financial knowledge questions ranging from 0 to 6 . Subjective financial knowledge was a self-assessment of financial knowledge with a range of 1-7 (1=very low, 7=very high). Desirable financial behavior was the number of desirable financial behaviors performed and reported by the respondents with a range of $0-5(0=$ no behavior is performed, $5=$ all five behaviors are performed). Financial capability was measured by two measures following previous research (Xiao and Porto 2017). Perceived financial capability was a self-assessment of money management ability with a range of 1-7 (1=very low, 7=very high). The financial capability index was constructed by summing up $\mathrm{Z}$ scores of the four indicators of financial capability.

Student loan holders were divided into three types, college students, graduates, and dropouts (see the data section for detailed specifications). Several socioeconomic variables, gender, race, marital status, having dependent children, employment status, age, and income were included to provide profiles of student loan holders and to be used for control variables in later regression analyses (Table 1).

\section{Data Analyses}

To test the hypotheses, both bivariate and multivariate analyses were conducted. As preliminary analyses, MANOVA were conducted among three student loan holder types on financial capability variables. In addition, multivariate OLS regressions were conducted by 


\section{Financial Capability of Student Loan Holders}

adding student loan holder types and control variables. To provide specific information for financial education, additional Chi-square tests on specific financial knowledge and behavior variables among student loan holder types were conducted.

\section{Results}

\section{Descriptive Statistics of the Sample}

Table 2 presents descriptive statistics of the sample. When profiles of three types of student loan holders are compared, two patterns emerge. First, college graduates and dropouts are similar as a group compared to college enrollees. College graduates and dropouts are more likely than enrollees to be male, white, married, older, and have dependent children. The second pattern is related to employment status and income. College graduates have the highest level, college enrollees have the lowest level, and college dropouts are in between in terms of employment status and income. These facts confirmed several assumptions we made in the conceptual framework section suggesting that most college enrollees are younger, single and less likely to be employed while still in college.

\section{Financial Capability by Student Loan Holder Type}

MANOVA results in Table 3 show group differences in all four indicators and the index of financial capability that demonstrate the same pattern, where financial capability variables are dependent variables and education attainment type is the independent variable. College graduates had higher scores on all four indicators and the index of financial capability than college dropouts and enrollees. For example, for objective financial knowledge, the mean score of college graduates was 3.43 out of a possible perfect score of 6 , while those of college dropouts and enrollees were 2.69 and 2.75 , respectively. The scores of college graduates were 


\section{Financial Capability of Student Loan Holders}

significantly higher than those of the other two groups, while the scores of college dropouts and enrollees were not statistically different from each other. The same patterns are shown in subjective financial knowledge, desirable financial behavior, perceived financial capability, and the index of financial capability.

OLS regression analyses on financial capability variables were conducted where control variables were added in addition to the education attainment variable and the results are presented in Table 4. Three main patterns emerged from these analyses. First, controlling for socioeconomic variables, when comparing the three student types, college graduates had the highest and dropouts had the lowest scores in objective financial knowledge, desirable financial behaviors and the index of financial capability. Second, college graduates had statistically higher scores than enrollees in perceived financial capability. Third, college dropouts had a lower score than enrollees in subjective financial knowledge.

\section{Additional Analyses}

Specific Financial Knowledge by Student Loan Holder Type. To gain more insights and provide more specific information for consumer educators, we conducted additional analyses on specific financial knowledge and financial behaviors by student loan holder types. Table 5 presents the results of Chi-square tests on specific financial knowledge, where financial knowledge variables are dependent variables and education attainment type is the independent variable. For the whole sample, the percentages, by topic, of respondents who correctly answered six financial knowledge questions were $76 \%$ (interest), 48\% (inflation), $23 \%$ (bond), 34\% (time value of money), 73\% (mortgage), and 38\% (stock), respectively. 


\section{Financial Capability of Student Loan Holders}

Chi-square tests results are statistically significant for all financial knowledge questions.

For the interest question, proportions of those having answered correctly among college graduates, dropouts, and enrollees were $79 \%, 72 \%$, and $77 \%$, respectively; $\chi^{2}(2, N=3,312)=$ $18.28, \mathrm{p}<0.001$. For the inflation question, proportions of those having answered correctly among college graduates, dropouts, and enrollees were $52 \%, 44 \%$, and $48 \%$, respectively; $\chi^{2}(2$, $\mathrm{N}=3,312)=27.21, \mathrm{p}<0.001$. For the bond question, proportions of those having answered correctly among college graduates, dropouts, and enrollees were $26 \%, 24 \%$, and $19 \%$, respectively; $\chi^{2}(2, \mathrm{~N}=3,312)=17.19, \mathrm{p}<0.001$. For the time value of money question, proportions of those having answered correctly among college graduates, dropouts, and enrollees were $39 \%, 31 \%$, and $31 \%$, respectively; $\chi^{2}(2, N=3,312)=36.26, p<0.001$. For the mortgage question, proportions of those having answered correctly among college graduates, dropouts, and enrollees were $81 \%, 68 \%$, and $71 \%$, respectively; $\chi^{2}(2, N=3,312)=93.79, p<0.001$.

A comparison of the three types of student loan holders, revealed four patterns. The first pattern demonstrated that college graduates and enrollees had significantly higher correct answer rates than that of college dropouts for the question about interest. as $79 \%$ of college graduates and $77 \%$ of college enrollees provided correct answers, higher than $72 \%$ of college dropouts who answered correctly. The question on inflation revealed pattern 2 , for which rates of the correct answer were $52 \%$ for graduates, $48 \%$ for enrollees, and $44 \%$ for dropouts, and that they were statistically different from each other. Pattern 3 emerged in the bond question where college graduates and dropouts as a group had significantly higher rates of correct responses than college enrollees, $26 \%$ for graduates and $24 \%$ for dropouts vs. $19 \%$ for enrollees. The last three questions showed pattern 4 , in which the rate of correct responses of college graduates was significantly higher than college dropouts and enrollees. For example, for the question of the 


\section{Financial Capability of Student Loan Holders}

time value of money, the correct answer rate of graduates was $39 \%$, higher than the $31 \%$ rate for both dropouts and enrollees. For the mortgage question, the correct answer rate of graduates was $81 \%$, a rate higher than $68 \%$ for dropouts and $71 \%$ for enrollees. For the stock question, the correct answer rate of graduates was $44 \%$, while it was $34 \%$ for dropouts and $36 \%$ for enrollees. Pattern 1 and 2 may reflect the effect of cognitive ability, pattern 3 may reflect the effect of life experience, and pattern 4 may reflect effects of both cognitive ability and life experience.

\section{Specific Financial Behaviors by Student Loan Holder Type. Table 6 presents the} results of Chi-square tests on specific desirable financial behaviors, where financial behavior variables are dependent variables and education attainment type is the independent variable. Among the whole sample, percentages of respondents performing these behaviors are $34 \%$ (underspending), 30\% (emergency saving), 57\% (budgeting), 57\% (goal setting), and 33\% (retirement need calculating), respectively.

Chi-square tests results are statistically significant for all financial behavior variables. For underspending behavior, proportions of those having answered yes among college graduates, dropouts, and enrollees were $40 \%, 29 \%$, and $32 \%$, respectively; $\chi^{2}(2, \mathrm{~N}=3,312)=36.19, \mathrm{p}<$ 0.001. For emergency saving behavior, proportions of those having answered yes among college graduates, dropouts, and enrollees were $42 \%, 19 \%$, and $25 \%$, respectively; $\chi^{2}(2, N=3,312)=$ 151.66, $\mathrm{p}<0.001$. For budgeting behavior, proportions of those having answered yes among college graduates, dropouts, and enrollees were $63 \%, 55 \%$, and $51 \%$, respectively; $\chi^{2}(2, \mathrm{~N}=$ $3,312)=33.43, \mathrm{p}<0.001$. For goal setting behavior, proportions of those having answered yes among college graduates, dropouts, and enrollees are $67 \%, 47 \%$, and 55\%, respectively; $\chi^{2}(2, \mathrm{~N}$ $=3,312)=107.75, \mathrm{p}<0.001$. For retirement needs calculating behavior, proportions of those 


\section{Financial Capability of Student Loan Holders}

having answered yes among college graduates, dropouts, and enrollees were $50 \%, 25 \%$, and $22 \%$, respectively; $\chi^{2}(2, \mathrm{~N}=3,312)=216.27, \mathrm{p}<0.001$.

Compared to the three types of student loan holders, two patterns are evident. The first pattern is that the proportions of self-reported specific behaviors of college graduates are higher than the other two groups. For the behavior of underspending, the performance rate is $40 \%$ for college graduates, higher than $29 \%$ for dropouts and $32 \%$ for enrollees. The same pattern is shown in other behaviors such as emergency saving (42\%, higher than 19\% and 25\%) and budgeting (63\%, higher than $55 \%$ and $51 \%)$. The second pattern refers to the situation in which three groups differ from each other in two self-reported financial behaviors. For goal setting, $67 \%$ of college graduates, $47 \%$ of dropouts, and $55 \%$ of enrollees reported this behavior. For retirement need calculating, $50 \%$ of college graduates, $35 \%$ of dropouts, and $22 \%$ of enrollees reported this behavior. These findings suggest that college graduates are more likely to perform desirable money management behaviors than college dropouts and enrollees.

\section{Discussions}

This study used a large scale, national data set to examine differences in financial capability variables among three types of student loan holders in terms of their college completion status. Compared to previous research, this study contributed to the literature by examining differences in five financial capability variables and differences in specific financial knowledge items and financial behaviors among three types of student loan holders.

The results of this study provided partial support for the three hypotheses. H1 (both college graduates and enrollees have higher levels of financial knowledge than college dropouts) is mostly supported by multivariate analysis results after several socioeconomic variables are 


\section{Financial Capability of Student Loan Holders}

controlled. In Table 4, college dropouts tend to score lower than the other two groups in both objective knowledge and subjective knowledge, consistent with H1. In addition, college graduates tend to score higher than college enrollees in objective knowledge, while there is no difference in subjective knowledge between the two groups, suggesting subtle differences between objective and subjective knowledge. The finding implies that two types of knowledge may have different effects on consumer behavior and wellbeing as indicated by previous research (Xiao et al. 2011).

$\mathrm{H} 2$ (both college graduates and dropouts perform more desirable financial behaviors) is also only partially supported. College graduates tend to report more desirable financial behaviors than the other two groups, which is consistent with $\mathrm{H} 2$, while the number of desirable financial behaviors reported by college dropouts is lower than that of college enrollees (Tables 4). Findings of specific financial behaviors show that college graduates are more likely to perform each of five financial behaviors than the other two groups, while for three specific behaviors, there are no differences between college enrollees and dropouts. This suggests that desirable financial behaviors may be impacted by not only cognitive ability and life experience, but also by other personality traits such as conscientiousness (Letkiewicz and Fox 2014).

H3 (college graduates have a higher level of financial capability than college dropouts and enrollees) is, again, partially supported. As measured by both the perceived financial capability and the financial capability index, college graduates displayed a higher level of financial capability than the other two groups, consistent with $\mathrm{H} 3$. In addition, there is no difference in perceived financial capability between college dropouts and enrollees but college enrollees tended to score higher than college dropouts in the financial capability index (Table 4). These findings suggest that in terms of financial capability, college graduates have the highest 


\section{Financial Capability of Student Loan Holders}

level, while college dropouts have the lowest level. Previous research suggests that college dropouts have different characteristics in terms of financial independence (Xiao et al. 2014). This study provides additional information to meet special education needs of various student loan holders including those who have borrowed student loans but do not complete their education program.

\section{Conclusion, Limitations, and Implications}

\section{Conclusion}

Using a large national data set from the U.S., this study has examined differences in financial capability among three types of student loan holders who are college students, graduates, and dropouts. Multivariate results show that college graduates tend to score the highest on all financial capability indicators, while college dropouts tend to score the lowest in these indicators. For specific financial knowledge, several group differences are shown. For specific financial behaviors, college graduates are more likely to perform all of them than college students and dropouts.

College students are, by definition, in a transitional state leading to either graduation or becoming dropouts. Recent data shows that $60 \%$ of first-time, full-time students graduate in 6 years or less (US Department of Education 2019). Roughly 1 in 3 students drop out during their first year of college. Those leaving college without a degree while still paying for student loans will start their professional life being disadvantaged on not just their educational attainment but also their financial capability.

\section{Limitations}




\section{Financial Capability of Student Loan Holders}

This study is limited to cross-sectional survey data that can only provide a snapshot of student loan holders and group differences in financial capability variables. To better understand long term consequences of student loan holding and financial capability, relevant longitudinal data are needed. Future research could also address how financial capability is developed among different student loan holders and how to help them enhance their financial capability and wellbeing. In addition, this study did not examine education differences in financial capability but education status differences among student loan holders. In future research, if educational differences in financial capability is studied, a different variable, education attainment, should be used for that purpose. Finally, while this study focused primarily on differences in financial capability among three types of student loan holders, other student loan variables such as loan type (federal and private) or if estimating monthly payment in advance may be of interest for future research focusing on different aspects of student loan holders.

\section{Implications}

Keeping limitations of the study in mind, the findings of this study have direct implications for consumer education. Research evidence continues to support the benefits of financial education for consumer wellbeing (Brown et al. 2014; Brown et al. 2016; Wagner and Walstad 2019; Kaiser et al. 2020). Financial educators should be aware of different needs of the three types of student loan holders. According to our results, college graduates have a higher level of financial capability than college students and dropouts, in which they are more likely to perform desirable financial behaviors and more knowledgeable in all specific knowledge items. Moreover, these results also suggest that improving the financial capability of college students while they are still in college might improve their chances to graduate. The data used in this study is cross-sectional so no claims of causality or directionality are feasible; however, the low 


\section{Financial Capability of Student Loan Holders}

level of financial capability of dropouts compared to the other two groups suggests that this may contribute to their inability to graduate. Financial education while in college would provide the opportunity to improve students' financial capability in terms of both knowledge and behavior and, presumably, also improve their chances to graduate.

Findings of this study suggest that when teaching financial education for the three types of student loan holders, different contents need to be stressed for different groups. Both college students and dropouts are less likely to perform desirable financial behaviors that could have been encouraged by education. Action-oriented education programs that are based on the theory of transtheoretical models of behavioral change (TTM) can be developed and delivered (Prochaska, DiClemente, and Norcross 1992; Xiao et al. 2004). For educational content design, specific findings of this study could be referenced to address deficiencies of financial knowledge of certain loan holder types such as college students and dropouts.

The results show that college dropouts have the lowest level of financial capability in terms of knowledge, behavior, and overall capability. As such, consumer educators, counselors and advisors offering financial education should pay special attention to clients that have dropped out from college. When college dropouts are identified, these consumer professionals can provide specific information to enhance their knowledge and strengthen their overall financial capability while encouraging them to engage in desirable financial behaviors. Many educational resources and tools developed by researchers and educators, available from Consumer Financial Protection Bureau (CFPB), National Endowment for Financial Education (NEFE), and other public education website can be used for these purposes. 


\section{Financial Capability of Student Loan Holders}

\section{References}

Agnew, Stephen, and Trudi Cameron-Agnew. 2015. The Influence of Consumer Socialisation in the Home on Gender Differences in Financial Literacy. International Journal of Consumer Studies, 39 (6): 630-638. doi.org/10.1111/ijcs.12179

Alsemgeest, Liezel. 2015. Arguments for and Against Financial Literacy Education: Where to Go from Here? International Journal of Consumer Studies, 39 (2): 155-161. doi: 10.1111/ijcs. 12163

Archuleta, Kristy L., Anita Dale, and Scott M. Spann. 2013. College Students and Financial Distress: Exploring Debt, Financial Satisfaction, and Financial Anxiety. Journal of Financial Counseling and Planning, 24 (2): 50-62.

Arnett, Jeffrey J. 2000. Emerging Adulthood: A Theory of Development from the Late Teens Through the Twenties." American Psychologist, 55 (5): 469-480. doi:10.1037//0003066X.55.5.469

Avery, Christopher, and Sarah Turner. 2012. Student Loans: Do College Students Borrow Too Much-Or Not Enough? Journal of Economic Perspectives, 26 (1): 165-192. doi: 10.1257/jep.26.1.165

Bartholomae, Suzanne, and Jonathan J. Fox. 2006. Advancing Financial Literacy Education Using a Framework for Evaluation." In Handbook of Consumer Finance Research, 2nd ed., edited by Jing Jiao Xiao (45-59). New York: Springer.

Braun Santos, Danilo, Wesley Mendes-Da-Silva, Eduardo Flores, and Jill M. Norvilitis. 2016. Predictors of Credit Card Use and Perceived Financial Well-Being in Female College Students: A Brazil-United States Comparative Study. International Journal of Consumer Studies, 40 (2): 133-142. doi.org/10.1111/ijcs.12234 


\section{Financial Capability of Student Loan Holders}

Britt, Sonya L., Anthony Canale, Fred Fernatt, Kristen Stutz, and Racquel Tibbetts. 2015. Financial Stress and Financial Counseling: Helping College Students. Journal of Financial Counseling and Planning, 26 (2): 172-186. http://dx.doi.org/10.1891/10523073.26.2.172

Brown, Alexandra, J. Michael Collins, Maximilian D. Schmeiser, and Carly Urban. 2014. State Mandated Financial Education and the Credit Behavior of Young Adults. No 2014-68, Finance and Economics Discussion Series, Board of Governors of the Federal Reserve System (US). http://EconPapers.repec.org/RePEc:fip:fedgfe:2014-68. (2014).

Brown, Meta, John Grigsby, Wilbert Van Der Klaauw, Jaya Wen, and Basit Zafar. 2016. Financial Education and the Debt Behavior of the Young. The Review of Financial Studies, 29 (9): 2490-2522. doi.org/10.1093/rfs/hhw006

Buenstorf, Guido, Kristian Nielsen, and Bram Timmermans. 2017. Steve Jobs or No Jobs? Entrepreneurial Activity and Performance Among Danish College Dropouts and Graduates. Small Business Economics, 48 (1): 179-197.

Burr, Matthew. 2016. Student Loan Repayment Assistance: A Perk for the New Generation of Workers.” (2016, April 26). Cornell HR Review. https://digitalcommons.ilr.cornell.edu/chrr/86

Chapman, Bruce. 2006. Income Related Student Loans: Concepts, International Reforms and Administrative Challenges. In Cost-Sharing and Accessibility in Higher Education: A Fairer Deal? (79-103). Dordrecht: Springer.

Chen, Rong, and Mark Wiederspan. 2014. Understanding the Determinants of Debt Burden Among College Graduates. The Journal of Higher Education, 85 (4): 565-598. doi.org/10.1080/00221546.2014.11777340 


\section{Financial Capability of Student Loan Holders}

Cho, Soo Hyun, Yilan Xu, and D. Elizabeth Kiss. 2015. Understanding Student Loan Decisions: A Literature Review." Family and Consumer Sciences Research Journal, 43 (3): 229243. doi.org/10.1111/fcsr.12099

Cigno, Alessandro, and Annalisa Luporini. 2009. Scholarships or Student Loans? Subsidizing Higher Education in the Presence of Moral Hazard. Journal of Public Economic Theory, 11 (1): 55-87. doi.org/10.1111/j.1467-9779.2008.01397.x

Darolia, Rajeev. 2016. An Experiment on Information Use in College Student Loan Decisions. FRB of Philadelphia Working Paper No. 16-18. https://ssrn.com/abstract=2805857

Erikson, Erik H. 1982. The Life Cycle Completed. New York: Norton.

Fan, Lu, and Swarn Chatterjee. 2019. Financial Socialization, Financial Education, and Student Loan Debt. Journal of Family and Economic Issues, 40 (1): 74-85.

Flint, Thomas A. 1997. Predicting Student Loan Defaults. The Journal of Higher Education, 68 (3): 322-354. doi.org/10.1080/00221546.1997.11778986

Henager, Robin, and Brenda J. Cude. 2016. Financial Literacy and Long-and Short-Term Financial Behavior in Different Age Groups. Journal of Financial Counseling and Planning, 27 (1): 3-19.

Hendricks, Lutz, and Oksana Leukhina. 2017. How Risky is College Investment? Review of Economic Dynamics, 26: 140-163.

Hill, Ronald Paul. 2019. Ready for the Revolution? Why Publishing Consumer Research is Changing. Journal of Consumer Affairs, 53 (3): 691-695.

Houle, Jason N. 2014. Disparities in Debt: Parents' Socioeconomic Resources and Young Adult Student Loan Debt. Sociology of Education, 87 (1): 53-69. doi.org/10.1177\%2F0038040713512213 


\section{Financial Capability of Student Loan Holders}

Huston, Sandra J. 2010. Measuring Financial Literacy. Journal of Consumer Affairs, 44 (2): 296316.

Johnson, Carrie L., Barbara O’Neill, Sheri Lokken Worthy, Jean M. Lown, and Cathy F. Bowen. 2016. What are Student Loan Borrowers Thinking? Insights from Focus Groups on College Selection and Student Loan Decision Making. Journal of Financial Counseling and Planning, 27 (2): 184-198.

Kaiser, T., Lusardi, A., Menkhoff, L., \& Urban, C. J. 2020. Financial Education Affects Financial Knowledge and Downstream Behaviors (No. w27057). National Bureau of Economic Research.

Kim, Jinhee, and Swarn Chatterjee. 2013. Childhood Financial Socialization and Young Adults' Financial Management. Journal of Financial Counseling and Planning, 24 (1): 61-79.

Kim, Jinhee, and Swarn Chatterjee. 2019. Student Loans, Health, and Life Satisfaction of US Households: Evidence from a Panel Study. Journal of Family and Economic Issues, 40 (1): $36-50$.

Kim, Jinhee, Swarm Chatterjee, and Jung Kim. 2012. Debt Burden of Young Adults in the United States. Journal of Financial Counseling and Planning, 23 (2): 55-67.

Lee, Jason, and John A. Mueller. 2014. Student Loan Debt Literacy: A Comparison of FirstGeneration and Continuing-Generation College Students. Journal of College Student Development, 55 (7): 714-719. doi: 10.1353/csd.2014.0074

Letkiewicz, Jodi C., and Jonathan J. Fox. 2014. Conscientiousness, Financial Literacy, and Asset Accumulation of Young Adults. Journal of Consumer Affairs, 48 (2): 274-300.

Lim, HanNa, Stuart Heckman, Catherine Phillips Montalto, and Jodi Letkiewicz. 2014. Financial 


\section{Financial Capability of Student Loan Holders}

Stress, Self-Efficacy, and Financial Help-Seeking Behavior of College Students. Journal of Financial Counseling and Planning, 25 (2): 148-160.

Lin, Judy T., Christopher Bumcrot, Tippy Ulicny, Annamaria Lusardi, Gary Mottola, Christine Kieffer, and Gerri Walsh. 2016. Financial Capability in the United States 2016. Washington, DC: FINRA Investor Education Foundation.

Lochner, Lance, and Alexander Monge-Naranjo. 2015. Student Loans and Repayment: Theory, Evidence and Policy. In 2015 Meeting Papers, no. 724. Society for Economic Dynamics. doi:10.3386/w20849

Looney, Adam, and Constantine Yannelis. 2015. A Crisis in Student Loans? How Changes in the Characteristics of Borrowers and in the Institutions They Attended Contributed to Rising Loan Defaults. Brookings Papers on Economic Activity (2): 1-89. doi:10.1353/eca.2015.0003

Lusardi, Annamaria, and Olivia S. Mitchell. 2014. The Economic Importance of Financial Literacy: Theory and Evidence. Journal of Economic Literature, 52 (1): 5-44. doi:org/10.3386/w18952

Miller, Laura. 2004. The Option that is Not an Option: The Invalidity of the Partial Discharge Option for the Student Loan Debtor. Wake Forest Law Review, 39: 1053-1078.

Montalto, Catherine P., Erica L. Phillips, Anne McDaniel, and Amanda R. Baker. 2019. College Student Financial Wellness: Student Loans and Beyond. Journal of Family and Economic Issues 40 (1): 3-21.

Montford, William, and Ronald E. Goldsmith. 2016. How Gender and Financial Self-efficacy Influence Investment Risk Taking. International Journal of Consumer Studies, 40 (1): 101-106. doi.org/10.1111/ijcs. 12219 


\section{Financial Capability of Student Loan Holders}

Murendo, Conrad, and Kingstone Mutsonziwa. 2017. Financial Literacy and Savings Decisions by Adult Financial Consumers in Zimbabwe. International Journal of Consumer Studies, 41 (1): 95-103. doi: 0.1111/ijcs. 12318

Newman, Barbara M., and Philip R. Newman, 1999. Development Through Life: A Psychosocial Approach. $7^{\text {th }}$ ed. Stamford: Cengage Learning.

Park, Seung Eun. 2019. Understanding Dropouts Among Community College Students: Using Cluster Analysis and Data Mining." In Essays on the Economics of Higher Education and Employment. PhD dissertation, Columbia University.

Prochaska, James O., Carlo C. DiClemente, and John C. Norcross. 1992. In Search of How People Change: Applications to Addictive Behaviors. American Psychologist, 47 (9): $1102-1114$.

Robb, Cliff A., Swarn Chatterjee, Nilton Porto, and Brenda J. Cude. 2019. The Influence of Student Loan Debt on Financial Satisfaction. Journal of Family and Economic Issues, 40 (1): 51-73.

Riitsalu, Leonore, and Kaire Põder. 2016. A Glimpse of the Complexity of Factors that Influence Financial Literacy. International Journal of Consumer Studies, 40 (6): 722-731. doi.org/10.1111/ijcs.12291

Schmeiser, Maximilian, Christiana Stoddard, and Carly Urban. 2016. Student Loan Information Provision and Academic Choices. American Economic Review 106 (5): 324-28. doi:10.1257/aer.p20161122

U.S. Department of Education, National Center for Education Statistics (NCES). 2019. The Condition of Education 2019 Undergraduate Retention and Graduation Rates (NCES 2019-144), Washington, D.C. https://nces.ed.gov/programs/coe/indicator_ctr.asp 


\section{Financial Capability of Student Loan Holders}

Wagner, Jamie, and William B. Walstad. 2019. The Effects of Financial Education on Short-term and Long-Term Financial Behaviors." Journal of Consumer Affairs, 53 (1): 234-259.

Walsemann, Katrina M., Gilbert C. Gee, and Danielle Gentile. 2015. Sick of our Loans: Student Borrowing and the Mental Health of Young Adults in the United States. Social Science \& Medicine 124: 85-93.

Xiao, Jing Jian, Swarn Chatterjee, and Jinhee Kim. 2014. Factors Associated with Financial Independence of Young Adults. International Journal of Consumer Studies, 38 (4): 394403. http://dx.doi.org/10.1111.ijcs. 12106

Xiao, Jing Jian, Cheng Chen, and Fuzhong Chen. 2014. Consumer Financial Capability and Financial Satisfaction." Social Indicators Research, 118 (1): 415-432. doi:org/10.1007/s11205-013-0414-8

Xiao, Jing Jian, Cheng Chen, and Lei Sun. 2015. Age Differences in Consumer Financial Capability. International Journal of Consumer Studies, 39 (4): 387-395. doi: $10.1111 /$ ijcs.12205

Xiao, Jing Jian, and Barbara O'Neill. 2016. Consumer Financial Education and Financial Capability. International Journal of Consumer Studies, 40 (6): 712-721.

Xiao, Jing Jian, Barbara O'Neill, Janice M. Prochaska, Claudia M. Kerbel, Patricia Brennan, and Barbara J. Bristow. 2004. A Consumer Education Programme Based on the Transtheoretical Model of Change." International Journal of Consumer Studies, 28 (1): 55-65. doi.org/10.1111/j.1470-6431.2004.00334.x

Xiao, Jing Jian, and Nilton Porto. 2017. Financial Education and Financial Satisfaction: Financial Literacy, Behavior, and Capability as Mediators. International Journal of Bank Marketing, 35 (5): 805-817. 


\section{Financial Capability of Student Loan Holders}

Xiao, Jing Jian, Chuanyi Tang, Joyce Serido, and Soyeon Shim. 2011. Antecedents and Consequences of Risky Credit Behavior among College Students: Application and Extension of the Theory of Planned Behavior. Journal of Public Policy \& Marketing, 30 (2): $239-245$.

Zhang, Qun, and Hyungsoo Kim. 2019. American Young Adults' Debt and Psychological Distress. Journal of Family and Economic Issues, 40 (1): 22-35. 
Financial Capability of Student Loan Holders

Table 1

Variable Specifications

\begin{tabular}{|c|c|c|}
\hline Variable name & Variable label & Attribute \\
\hline & Financial capability & \\
\hline $\begin{array}{l}\operatorname{Sum}(\mathrm{m} 6, \mathrm{~m} 7 \\
\mathrm{m} 8, \mathrm{~m} 31, \mathrm{~m} 9 \\
\mathrm{~m} 10)\end{array}$ & Objective financial literacy & $\begin{array}{l}0-6 \text {, the sum of correct numbers for financial literacy } \\
\text { questions. The original financial literacy variables (m6- } \\
\text { m10) were recoded to binary variables in which } 1=\text { correct } \\
\text { answer, } 0=\text { otherwise and then the new variables were } \\
\text { summed to form the score. These questions asked financial } \\
\text { knowledge about interest (m6), inflation (m7), bond (m8), } \\
\text { loan (m31), mortgage (m9), and stock (m10). More details } \\
\text { about these questions can be found at Lin et al. (2016). }\end{array}$ \\
\hline M4 & Subjective financial literacy & $\begin{array}{l}\text { The question is "On a scale from } 1 \text { to } 7 \text {, where } 1 \text { means } \\
\text { very low and } 7 \text { means very high, how would you assess } \\
\text { your overall financial knowledge?" }\end{array}$ \\
\hline $\begin{array}{l}\operatorname{Sum}(\mathrm{J} 3, \mathrm{~J} 5, \\
\text { J31, J33, J8J9) }\end{array}$ & Desirable financial behavior & $\begin{array}{l}\text { The sum of five desirable financial behaviors: spending } \\
\text { within income (J3), saving for emergency (J5), budgeting } \\
\text { (J31), setting financial goals (J33), and calculating } \\
\text { retirement needs (J8 and J9). All of these variables are } \\
\text { appropriately recoded to binary variables. }\end{array}$ \\
\hline \multirow[t]{3}{*}{ M1_1 } & $\begin{array}{l}\text { Perceived financial } \\
\text { capability }\end{array}$ & $\begin{array}{l}\text { The question is "I am good at dealing with day-to-day } \\
\text { financial matters, such as checking accounts, credit and } \\
\text { debit cards, and tracking expenses," 1-strongly disagree, 7- } \\
\text { strongly agree. }\end{array}$ \\
\hline & Financial capability index & $\begin{array}{l}\text { A sum of } \mathrm{Z} \text { scores of objective knowledge, subjective } \\
\text { knowledge, financial behavior, and perceived financial } \\
\text { capability variables. }\end{array}$ \\
\hline & Student loan variables & \\
\hline \multirow[t]{2}{*}{$\begin{array}{l}\text { G34, A5, } \\
\text { A22_2015 }\end{array}$} & Education attainment type & $\begin{array}{l}\text { The question is "Did you complete the most recent } \\
\text { educational program for which you borrowed } \\
\text { money?" } 1=y e s, 2=\text { no, } 3=\text { still enrolled in the program. } \\
\text { Graduates (G34=1 and A5=6, 7), Dropouts (G34=2, and } \\
\text { A5-4), Enrolled (G34=3 and A22_2015=1) }\end{array}$ \\
\hline & Socioeconomic variables & \\
\hline $\mathrm{a} 3$ & Being female (vs. male) & Recoded, $1=$ female, $0=$ male \\
\hline A4a_new_w & Being Non-White & Recoded, $1=$ non-white, $0=$ white \\
\hline a6 & Being married & Recoded, $1=$ married, $0=$ not married \\
\hline a11 & Having dependent children & Recoded, $1=$ yes, $0=$ no \\
\hline a9 & Working & Recoded, $1=$ yes, $0=$ no \\
\hline A3Ar_w & Age group & $\begin{array}{l}\text { Recoded to } 3 \text { age groups: } \\
1-18-34 \\
2-35-54 \\
3-55 \text { or older }\end{array}$ \\
\hline $\mathrm{a} 8$ & Income level & $\begin{array}{l}\text { Recoded to } 4 \text { income levels: } \\
1 \text {-Less than } \$ 25,000 \\
\text { 2-At least } \$ 25,000 \text { but less than } \$ 50,000 \\
\text { 3-At least } \$ 50,000 \text { but less than } \$ 75,000 \\
\text { 4-At least } \$ 75,000 \text { or more }\end{array}$ \\
\hline
\end{tabular}


Financial Capability of Student Loan Holders

Table 2

Descriptive Statistics of the Sample (\%)

\begin{tabular}{lccc}
\hline & Graduates & Dropouts & Enrollees \\
\hline Gender (Female=1) & $60 \%$ & $63 \%$ & $66 \%$ \\
Age 18-34 & $55 \%$ & $57 \%$ & $86 \%$ \\
Age 35-54 & $38 \%$ & $36 \%$ & $12 \%$ \\
Age 55 or older & $7 \%$ & $6 \%$ & $2 \%$ \\
Income under $\$ 25,000$ & $13 \%$ & $37 \%$ & $57 \%$ \\
Income $\$ 25,000-\$ 49,999$ & $25 \%$ & $35 \%$ & $21 \%$ \\
Income $\$ 50,000-\$ 74,999$ & $41 \%$ & $24 \%$ & $16 \%$ \\
Income $\$ 75,000$ or higher & $21 \%$ & $4 \%$ & $6 \%$ \\
Ethnicity (White=1) & $64 \%$ & $60 \%$ & $54 \%$ \\
Married=1 & $51 \%$ & $38 \%$ & $14 \%$ \\
Dependent Child(ren)=1 & $48 \%$ & $48 \%$ & $22 \%$ \\
Working=1 & $84 \%$ & $58 \%$ & $30 \%$ \\
\hline Observations $(3,312)$ & 2,065 & 762 & 485 \\
\hline FINRA 2015 Nation
\end{tabular}

FINRA 2015 National Financial Capability Study 
Financial Capability of Student Loan Holders

Table 3

Result of MANOVA of Financial Capability Indicators

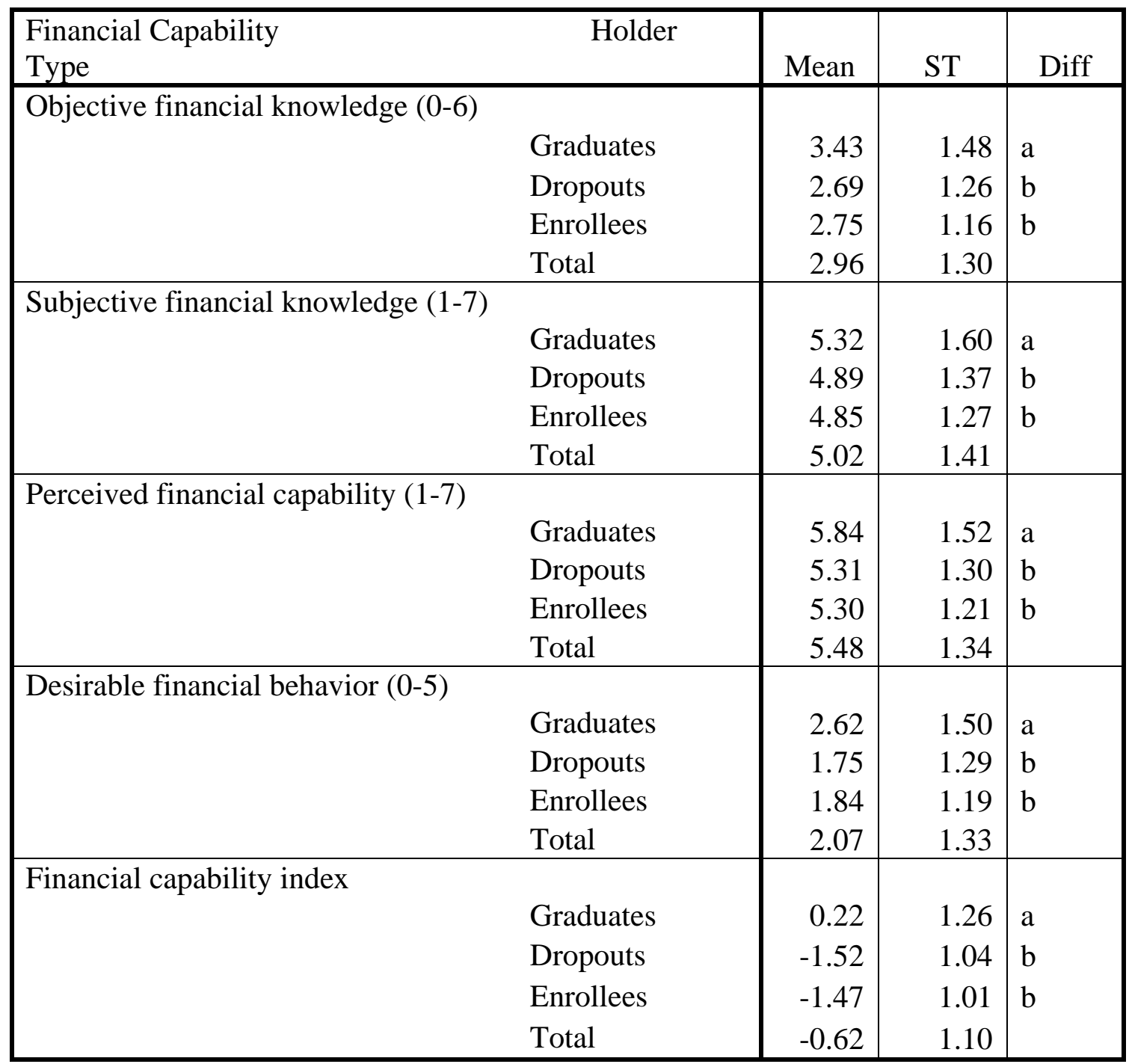

Note. In the column "Diff," group a is statistically different from group b at significance level of $1 \%$ based on post hoc tests. For example, for objective financial knowledge, the mean score of college graduates is significantly higher than the other two groups, while there is no difference between scores of college dropouts and enrollees. 
Financial Capability of Student Loan Holders

Table 4: OLS Regression Results on Financial Capability Variables

\begin{tabular}{|c|c|c|c|c|c|}
\hline & $\begin{array}{c}(1) \\
\text { Objective } \\
\text { Financial } \\
\text { Knowledge } \\
\text { b/se }\end{array}$ & $\begin{array}{c}\text { (2) } \\
\text { Subjective } \\
\text { Financial } \\
\text { Knowledge } \\
\text { b/se }\end{array}$ & $\begin{array}{c}\text { (3) } \\
\text { Perceived } \\
\text { Financial } \\
\text { Capability } \\
\text { b/se }\end{array}$ & $\begin{array}{c}(4) \\
\text { Desirable } \\
\text { Financial } \\
\text { Behaviors } \\
\text { b/se }\end{array}$ & $\begin{array}{c}\text { (5) } \\
\text { Financial } \\
\text { Capability } \\
\text { Index } \\
\text { b/se }\end{array}$ \\
\hline \multicolumn{6}{|l|}{ Loan Type (ref: Enrolled) } \\
\hline Graduates & $\begin{array}{c}0.3599^{* * *} \\
(0.085)\end{array}$ & $\begin{array}{l}0.1152 \\
(0.073)\end{array}$ & $\begin{array}{c}0.3231^{* *} \\
(0.096)\end{array}$ & $\begin{array}{c}0.3706^{* * *} \\
(0.073)\end{array}$ & $\begin{array}{c}0.7872^{* * * *} \\
(0.141)\end{array}$ \\
\hline Dropouts & $\begin{array}{c}-0.1947^{*} \\
(0.095)\end{array}$ & $\begin{array}{c}-0.1484^{*} \\
(0.072)\end{array}$ & $\begin{array}{c}-0.0778 \\
(0.098)\end{array}$ & $\begin{array}{c}-0.1946^{* *} \\
(0.071)\end{array}$ & $\begin{array}{c}-0.4246^{* * *} \\
(0.131)\end{array}$ \\
\hline Female $=1$ & $\begin{array}{c}-0.4519^{* * *} \\
(0.065)\end{array}$ & $\begin{array}{c}-0.4285^{* * *} \\
(0.035)\end{array}$ & $\begin{array}{r}-0.0760 \\
(0.049)\end{array}$ & $\begin{array}{c}-0.2204^{* * * *} \\
(0.042)\end{array}$ & $\begin{array}{c}-0.8290^{* * * *} \\
(0.073)\end{array}$ \\
\hline \multicolumn{6}{|l|}{ Age (ref: 18-34) } \\
\hline $35-54$ & $\begin{array}{c}0.3083^{* * *} \\
(0.063)\end{array}$ & $\begin{array}{l}0.0484 \\
(0.044)\end{array}$ & $\begin{array}{r}-0.0183 \\
(0.067)\end{array}$ & $\begin{array}{c}-0.3481^{\text {**** }} \\
(0.047)\end{array}$ & $\begin{array}{c}-0.0163 \\
(0.105)\end{array}$ \\
\hline 55 and older & $\begin{array}{c}0.5791^{* * * *} \\
(0.122)\end{array}$ & $\begin{array}{l}0.0925 \\
(0.090)\end{array}$ & $\begin{array}{c}0.2829^{* *} \\
(0.098)\end{array}$ & $\begin{array}{c}-0.1096 \\
(0.095)\end{array}$ & $\begin{array}{c}0.5554^{* * *} \\
(0.157)\end{array}$ \\
\hline \multicolumn{6}{|l|}{ Income (ref: under $\$ 25,000$ ) } \\
\hline$\$ 25,000-\$ 49,999$ & $\begin{array}{c}0.2213^{* * *} \\
(0.072)\end{array}$ & $\begin{array}{c}0.2636^{* * *} \\
(0.065)\end{array}$ & $\begin{array}{c}0.0739 \\
(0.076)\end{array}$ & $\begin{array}{c}0.1598^{*} \\
(0.076)\end{array}$ & $\begin{array}{c}0.5114^{* * * *} \\
(0.137)\end{array}$ \\
\hline$\$ 50,000-\$ 74,999$ & $\begin{array}{c}0.2772^{* * * *} \\
(0.072)\end{array}$ & $\begin{array}{c}0.3657^{* * * *} \\
(0.068)\end{array}$ & $\begin{array}{c}0.2369^{* *} \\
(0.086)\end{array}$ & $\begin{array}{c}0.5973^{* * *} \\
(0.072)\end{array}$ & $\begin{array}{c}1.0344^{* * * *} \\
(0.128)\end{array}$ \\
\hline$\$ 75,000$ or higher & $\begin{array}{c}0.6292^{* * *} \\
(0.106)\end{array}$ & $\begin{array}{c}0.4661^{\text {**** }} \\
(0.071)\end{array}$ & $\begin{array}{c}0.3462^{* * * *} \\
(0.080)\end{array}$ & $\begin{array}{c}0.9044^{* * * *} \\
(0.080)\end{array}$ & $\begin{array}{c}1.6095^{* * * *} \\
(0.140)\end{array}$ \\
\hline Race (White = 1) & $\begin{array}{c}0.4623^{* * *} \\
(0.055)\end{array}$ & $\begin{array}{c}-0.1539^{* * * *} \\
(0.034)\end{array}$ & $\begin{array}{l}0.0503 \\
(0.049)\end{array}$ & $\begin{array}{c}-0.1384^{* * *} \\
(0.050)\end{array}$ & $\begin{array}{l}0.0936 \\
(0.075)\end{array}$ \\
\hline Married $=1$ & $\begin{array}{l}0.0702 \\
(0.071)\end{array}$ & $\begin{array}{l}0.0877 \\
(0.061)\end{array}$ & $\begin{array}{l}0.1523^{*} \\
(0.067)\end{array}$ & $\begin{array}{c}0.2254^{* * * *} \\
(0.061)\end{array}$ & $\begin{array}{c}0.3727^{* *} \\
(0.120)\end{array}$ \\
\hline Dependent Child(ren) & $\begin{array}{c}-0.2834^{* * * *} \\
(0.074)\end{array}$ & $\begin{array}{c}0.2790^{* * * *} \\
(0.044)\end{array}$ & $\begin{array}{c}-0.0105 \\
(0.055)\end{array}$ & $\begin{array}{l}0.1390^{*} \\
(0.067)\end{array}$ & $\begin{array}{l}0.1474 \\
(0.096)\end{array}$ \\
\hline Employment (working=1) & $\begin{array}{l}0.0283 \\
(0.072)\end{array}$ & $\begin{array}{l}0.0950 \\
(0.055)\end{array}$ & $\begin{array}{l}0.0409 \\
(0.065)\end{array}$ & $\begin{array}{l}0.1625^{*} \\
(0.062)\end{array}$ & $\begin{array}{l}0.2325 \\
(0.116)\end{array}$ \\
\hline Constant & $\begin{array}{c}2.6715^{* * *} \\
(0.095)\end{array}$ & $\begin{array}{c}4.9621^{* * * *} \\
(0.082)\end{array}$ & $\begin{array}{c}5.2243^{* * *} \\
(0.091)\end{array}$ & $\begin{array}{c}1.8166^{* * *} \\
(0.087)\end{array}$ & $\begin{array}{c}-1.5123^{* * *} \\
(0.150)\end{array}$ \\
\hline Observations & 3.312 & 3.312 & 3.312 & 3.312 & 3,312 \\
\hline
\end{tabular}

FINRA 2015 National Financial Capability Study

${ }^{*} p<0.05,{ }^{* *} p<0.01,{ }^{* * *} p<0.001$ 
Financial Capability of Student Loan Holders

Table 5

Chi-square Test Results on Specific Financial Knowledge

\begin{tabular}{|c|c|c|c|}
\hline Financial Knowledge & Holder Type & $\%$ & Diff \\
\hline $\begin{array}{l}\text { Interest } \\
\mathrm{X}^{2}=18.28, \mathrm{p}<.001, \text { Cramér's } \mathrm{V}=.074\end{array}$ & $\begin{array}{l}\text { Graduates } \\
\text { Dropouts } \\
\text { Enrollees } \\
\text { Total sample }\end{array}$ & $\begin{array}{l}79 \\
72 \\
77 \\
76\end{array}$ & $\begin{array}{l}\mathrm{a} \\
\mathrm{b} \\
\mathrm{a}\end{array}$ \\
\hline $\begin{array}{l}\text { Inflation } \\
X^{2}=27.21, p<.001, \text { Cramér's } V=.071\end{array}$ & $\begin{array}{l}\text { Graduates } \\
\text { Dropouts } \\
\text { Enrollees } \\
\text { Total sample }\end{array}$ & $\begin{array}{l}52 \\
44 \\
48 \\
48\end{array}$ & $\begin{array}{l}\mathrm{a} \\
\mathrm{b} \\
\mathrm{c}\end{array}$ \\
\hline $\begin{array}{l}\text { Bond } \\
\mathrm{X}^{2}=17.19, \mathrm{p}<.001, \text { Cramér's } \mathrm{V}=.056\end{array}$ & $\begin{array}{l}\text { Graduates } \\
\text { Dropouts } \\
\text { Enrollees } \\
\text { Total sample }\end{array}$ & $\begin{array}{l}26 \\
24 \\
19 \\
23\end{array}$ & $\begin{array}{l}a \\
a \\
b\end{array}$ \\
\hline $\begin{array}{l}\text { TVM } \\
\mathrm{X}^{2}=36.26, \mathrm{p}<.001, \text { Cramér's V=.082 }\end{array}$ & $\begin{array}{l}\text { Graduates } \\
\text { Dropouts } \\
\text { Enrollees } \\
\text { Total sample }\end{array}$ & $\begin{array}{l}39 \\
31 \\
31 \\
34\end{array}$ & $\begin{array}{l}a \\
b \\
b\end{array}$ \\
\hline $\begin{array}{l}\text { Mortgage } \\
X^{2}=93.79, p<.001, \text { Cramér's } V=.132\end{array}$ & $\begin{array}{l}\text { Graduates } \\
\text { Dropouts } \\
\text { Enrollees } \\
\text { Total sample }\end{array}$ & $\begin{array}{l}81 \\
68 \\
71 \\
73\end{array}$ & $\begin{array}{l}a \\
b \\
b\end{array}$ \\
\hline $\begin{array}{l}\text { Stock } \\
\mathrm{X}^{2}=46.84, \mathrm{p}<.001, \text { Cramér's } V=.093\end{array}$ & $\begin{array}{l}\text { Graduates } \\
\text { Dropouts } \\
\text { Enrollees } \\
\text { Total sample }\end{array}$ & $\begin{array}{l}44 \\
34 \\
36 \\
38\end{array}$ & $\begin{array}{l}a \\
b \\
b\end{array}$ \\
\hline
\end{tabular}

Note. For all tests, $\mathrm{DF}=2, \mathrm{~N}=3.312$. In the column "Diff," group a is statistically different from group $b$ at significance level of $5 \%$ or better based on post hoc tests. For example, for the "interest" question, the correct answer rate of college dropouts is significantly lower than the other two groups, while there is no difference in correct answer rates between college graduates and enrollees. 
Financial Capability of Student Loan Holders

Table 6

Chi-square Test Results on Specific Financial Behaviors

\begin{tabular}{|c|c|c|c|}
\hline $\begin{array}{l}\text { Desirable Financial Behavior } \\
\text { Type }\end{array}$ & Holder & $\%$ & Diff \\
\hline $\begin{array}{l}\text { Underspending } \\
\mathrm{X}^{2}=36.19, \mathrm{p}<.001 \text {, Cramér's } \mathrm{V}=.105\end{array}$ & $\begin{array}{l}\text { Graduates } \\
\text { Dropouts } \\
\text { Enrollees } \\
\text { Total sample }\end{array}$ & $\begin{array}{l}40 \\
29 \\
32 \\
34\end{array}$ & $\begin{array}{l}a \\
b \\
b\end{array}$ \\
\hline $\begin{array}{l}\text { Saving for emergency } \\
X^{2}=151.66, p<.001 \text {, Cramér's } V=.214\end{array}$ & $\begin{array}{l}\text { Graduates } \\
\text { Dropouts } \\
\text { Enrollees } \\
\text { Total sample }\end{array}$ & $\begin{array}{l}42 \\
19 \\
25 \\
30\end{array}$ & $\begin{array}{l}\mathrm{a} \\
\mathrm{b} \\
\mathrm{c}\end{array}$ \\
\hline $\begin{array}{l}\text { Budgeting } \\
\mathrm{X}^{2}=33.43, \mathrm{p}<.001 \text {, Cramér's } \mathrm{V}=.101\end{array}$ & $\begin{array}{l}\text { Graduates } \\
\text { Dropouts } \\
\text { Enrollees } \\
\text { Total sample }\end{array}$ & $\begin{array}{l}63 \\
55 \\
51 \\
57\end{array}$ & $\begin{array}{l}a \\
b \\
b\end{array}$ \\
\hline $\begin{array}{l}\text { Setting goals } \\
X^{2}=107.75, p<.001, \text { Cramér's } V=.180\end{array}$ & $\begin{array}{l}\text { Graduates } \\
\text { Dropouts } \\
\text { Enrollees } \\
\text { Total sample }\end{array}$ & $\begin{array}{l}67 \\
47 \\
55 \\
57\end{array}$ & $\begin{array}{l}\mathrm{a} \\
\mathrm{b} \\
\mathrm{c}\end{array}$ \\
\hline $\begin{array}{l}\text { Calculating retirement needs } \\
\mathrm{X}^{2}=216.27, \mathrm{p}<.001, \text { Cramér's } V=.255\end{array}$ & $\begin{array}{l}\text { Graduates } \\
\text { Dropouts } \\
\text { Enrollees } \\
\text { Total sample }\end{array}$ & $\begin{array}{l}50 \\
25 \\
22 \\
33\end{array}$ & $\begin{array}{l}a \\
b \\
b\end{array}$ \\
\hline
\end{tabular}

Note. In the column "Diff," group a is statistically different from group b at significance level of $5 \%$ or better based on post hoc tests. For example, for the "underspending" behavior, the performing rate of college graduates is significantly higher than the other two groups, while there is no difference in performing rates between college dropouts and enrollees. 
Figure 1.

Conceptual Considerations of Financial Capability by Student Loan Holder Type.
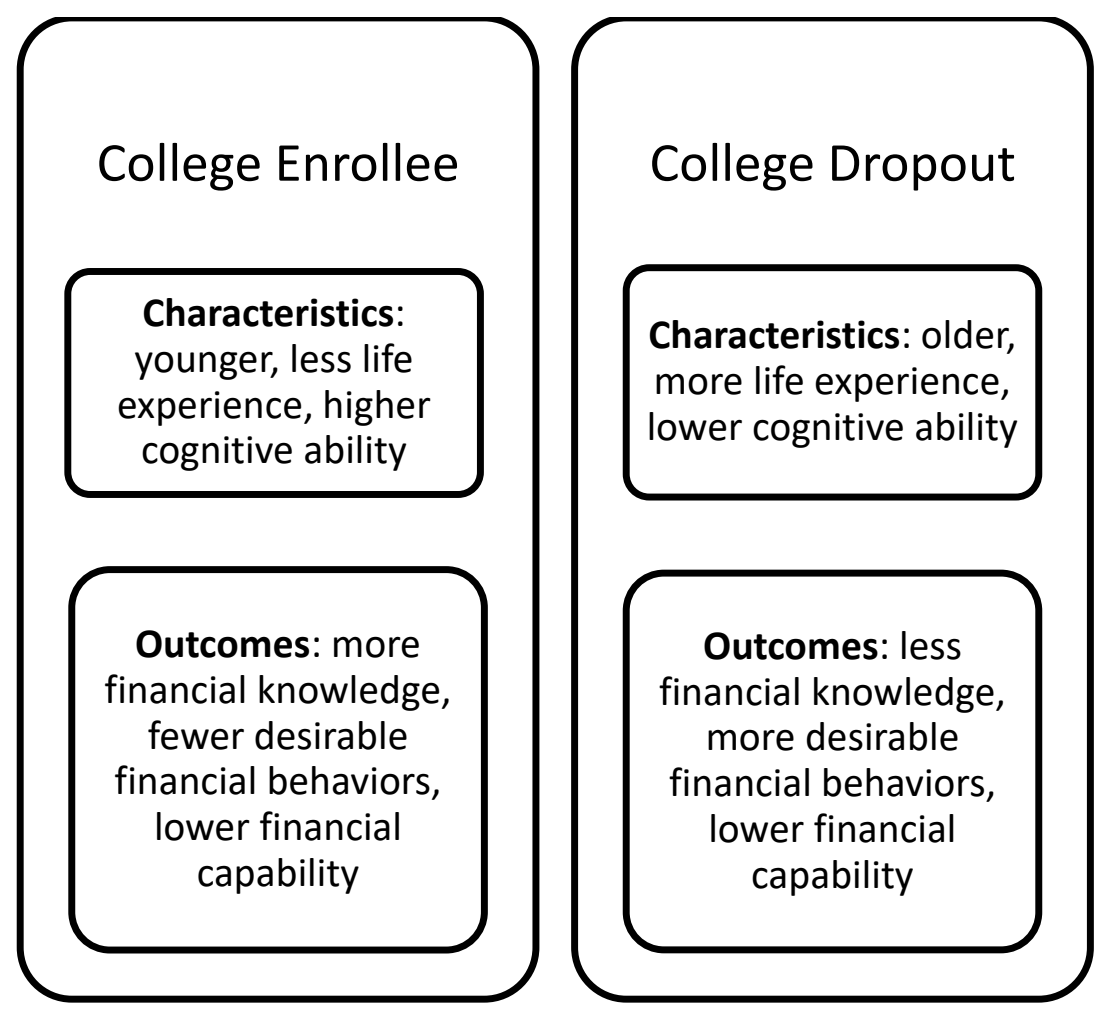

College Graduate

Characteristics: older, more life experience, higher cognitive ability

Outcomes: more financial knowledge, more desirable financial behaviors, higher financial capability 